\title{
Incidence of louse flies on birds from the Russian Far East (Diptera: Hippoboscidae) and investigation of the status of some taxa by DNA barcoding
}

\section{O заражкении птиц кровососками (Diptera: Hippoboscidae) на Аальнем Востоке России и использование АНК-штрих- кодирования дАя проверки статуса некоторых таксонов}

\author{
B.R. Meißner ${ }^{1}$, F. Rodríguez-Vera ${ }^{2}$, O. Hawlitschel ${ }^{2,3}$, W. Heim ${ }^{4}$, M. Jentzsch ${ }^{*}$ \\ Б.P. Мейснер ${ }^{1}$, Ф. Родригес-Вера ${ }^{2}$, О. Хауличек ${ }^{2,3}$, В. Хайм ${ }^{4}$, М. Йенч ${ }^{1 *}$ \\ ${ }^{1}$ Dresden University of Applied Sciences, Faculty Agriculture/Environment/Chemistry, Pillnitzer Platz 2, 01326 Dresden, Germany. E- \\ mail: matthias.jentzsch@htw-dresden.de. \\ 2 Zoologische Staatssammlung, Münchhausenstraße 21, 81247 München, Germany. E-mail: felrod1992@gmail.com. \\ ${ }^{3}$ Centrum für Naturkunde (CeNak), Universität Hamburg, Zoological Museum, Martin-Luther-King-Platz 3, 20146 Hamburg, Germany. E- \\ mail: oliver.hawlitschek@gmx.de. \\ ${ }^{4}$ Institute of Landscape Ecology, University of Münster, Heisenbergstraße 2, 48149 Münster, Germany. E-mail: wieland.heim@uni- \\ muenster.de. \\ * Corresponding author.
}

KEY WORDS: Hippoboscidae, Louse Flies, phoresy, Russian Far East.

КЛЮЧЕВЫЕ СЛОВА: Нippoboscidae, кровососки, форезия, Дальний Восток России.

ABSTRACT. We report seven species of bird louse flies (Hippoboscidae) collected from 33 bird hosts from Muraviovka Park for Sustainable Land Use (Oblast Amur, Russia). Overall, there is a distinct majority of female flies. Our record of Icosta holoptera represents the first observation in Russia. DNA barcoding showed Ornithomya aobatonis as a valid species (stat. rev., Ornithomya avicularia aobatonis). This species is the one most frequently observed in our investigations. Our records represent a westward expansion of the known distribution ranges of all species, which were previously restricted to an isolated area in the easternmost part of Russia and the neighboring border regions. Our records of Ornithomya chloropus suggest a gap closure the western distribution area. Five of the louse flies (5.6\%) served as phorents for mites (Acari) and their egg deposits.

РЕЗЮМЕ. В ходе нашего исследования в Муравьёвском парке (Амурская область, Россия) были обнаружены семь видов мух-кровососок (Нірроboscidae) на 33 птицах-хозяевах. В большей степени, в отловах доминировали самки. Icosta holoptera был обнаружен в России впервые. Штрих-кодирование ДНК показало, что Ornithomya aobatonis заслуживает статуса самостоятельного вида (stat. rev., O. avicularia aobatonis). Этот вид был наиболее обы- чен в наших материалах. Исследования показали, что для всех видов, граница ареала которых проходила по самому востоку России и приграничным территориям, отмечены более западные находки. Для Ornithomya chloropus наши результаты предполагают отсутствие разрыва между восточной и западной популяциями. Пять из отловленных кровососок $(5,6 \%)$, оказались переносчиками клещей (Acari) и их яиц.

\section{Introduction}

Louse flies are obligate bloodsucking parasites of mammals and birds and have occasionally been known to attack humans [Mehlhorn, Piekarski, 2002; Lucius et al., 2018]. Because of the varied degree of host specificity within these insects, a distinction is made between monoxene, oligoxene, and polyxene species [Büttiker, 1994]. Usually, the effect of louse flies on their hosts is insignificant, but an increased mortality rate has occasionally been observed in juvenile birds [Sellenschlo, 1984; Lucius et al., 2018].

Some species with hosts that live in colonies (e.g. Stenepteryx hirundinis on Delichon urbicum) or in larger flocks (e. g. Melophagus ovinus on Ovis gmelini

How to cite this article: Meißner B.R., Rodríguez-Vera F., Hawlitschek O., Heim W., Jentzsch M. 2020. Incidence of louse flies on birds from the Russian Far East (Diptera: Hippoboscidae) and investigation of the status of some taxa by DNA barcoding // Russian Entomol. J. Vol.29. No.3. P.327-335. doi: 10.15298/rusentj.29.3.14 
aries) are wingless or have wings with a partial or complete loss of function. It is also interesting to note that Acari and Mallophaga use flying Hippoboscidae for the purpose of travel (phoresy) [Büttiker, 1994; Labitzke et al., 2018; Matyukhin, 2016; Walter, 1989].

With 213 species in 21 genera, Hippoboscidae are a relatively small family of the order Diptera (true flies) and assigned to the Brachycera. These insects are distributed in nearly all geographic regions of the world [Maa, 1977; Soós, Hùrka, 1986; Dick, 2006].

Doszhanov [2003] mention 49 species of louse flies that occur in the Palearctic region. Nartshuk and Matyukhin [2019] added Ornithophila metallica and Ornithophila gestroi. In the eastern Palearctic in particular, there are several publications about louse fly records. Maa [1967], Mogi et al. [2002] and Sato and Mogi [2008] mention a total of 26 species present in Japan. In China, Sun [1999] found a total of nine species and the same number of species has been reported from Mongolia [Maa, 1963; Kristofik, Kiefer, 1983; Jentzsch et al., in preparation]. Finally, the list of louse flies in Korea describes the presence of 13 species [Iwasa, Choi, 2013]. From the Russian Far East, data on of 16 louse fly species has been published [Soós, Hùrka, 1986; Farafonova, 2001; Nartshuk et al., 2018].

While there is some amount of distribution data, only very little genetic data on louse flies are available worldwide. As of 09 April 2020, the Barcode of Life Data Systems database (BOLD) [Ratnasingham, Hebert, 2007] lists 410 published DNA barcode records of Hippoboscidae out of more than 2,000,000 dipteran records. None of the published records of louse flies are from Eastern Asia or from any part of Russia. A thorough DNA barcoding database is a prerequisite for large-scale biodiversity assessments and metabarcoding studies [Taberlet, 2012], but so far, the Russian Far East (as many parts of Northern Asia) has been targeted by only a very limited number of pioneering studies [Grebennikov et al., 2017; Kirichenko et al.; 2019, Makarchenko et al., 2015].

The bird-ringing station at the Muraviovka Park for Sustainable Land Use $\left(49^{\circ} 55^{\prime} \mathrm{N}, 127^{\circ} 40^{\prime} \mathrm{E}\right.$, Fig. 1) is

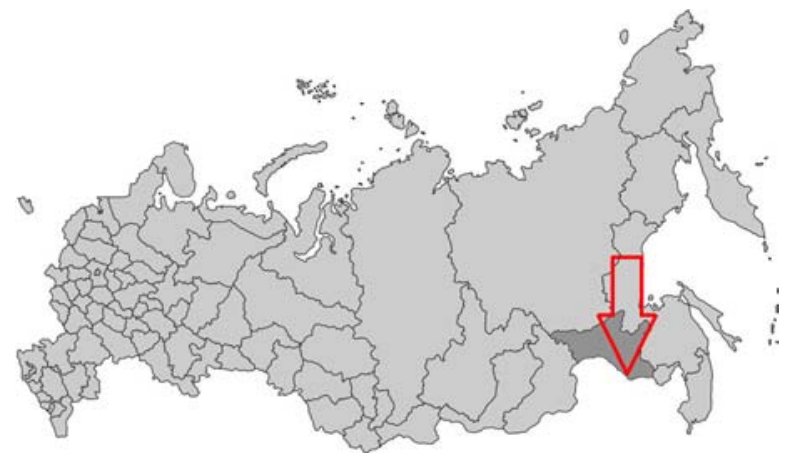

Fig. 1. Location of Muraviovka Park (arrow) within the Oblast Amur (dark grey).

Рис. 1. Расположение парка Муравьёвка (стрелка) в Амурской области (темно-серая заливка). located $50 \mathrm{~km}$ south of Blagoveshchensk at the middle section of the river Amur in the southern Zeya-Bureya plane (Amur Region, Russia). Founded in 1994, this privately owned and operated park covers some 6,500 hectares of wetlands, meadows, fields and small woods. The wetlands meet the IBA criteria (Important Birds Area) and the guidelines of the Ramsar Convention (listed since 1995). Research in the field of bird migration has been conducted there since 2011 [Heim, Smirenski, 2013, 2017].

In 2017, birds caught for ringing were examined for the occurrence of louse flies. The faunistic results of the collection of Hippoboscidae were incorporated into a bachelor's thesis at the Dresden University of Applied Sciences (Germany) [Meißner, 2019]. The goal of the study was to give a contribution to the louse fly fauna of the Far East of Russia. At the same time, the material was to be compared with that of some Hippoboscidae from Europe on the basis of the DNA barcode in order to biochemically check the respective species or subspecies affiliations, to compare it with the taxonomic findings and to discover cryptic species.

\section{Material and Methods}

In 2017, ringers of the bird-ringing station caught the birds by net ( 250 net meters) and marked them individually with rings of the Bird Ringing Centre of Russia. The objective was to gain insight into the phenology, behaviour and population trends of migrating songbirds [Heim 2017, Heim et al., 2018].

We examined a total of 7,222 birds representing 128 species, and collected louse flies during the spring (28 April to 13 July 2017) and autumn season (25 July to 21 September 2017). To preserve the insects, $2.0 \mathrm{ml}$ twisttop vials containing $100 \%$ undenatured ethyl alcohol (both BioForm) were used. Some louse flies left the host before collection and had to be caught on the window or walls in the station room and were not assigned to a host specimen.

To identify the louse fly species, we used a stereobinocular SMZ 745T (Nikon) microscope, the VHX5000 (Keyence) digital microscope and numerous literature resources [Büttiker, 1994; Doszhanov, 2003; Grunin, 1989; Farafonova, 2001; Iwasa, Choi, 2015; Maa, 1962; 1963, 1966a-b, 1967, 1969a-d; Nartshuk et al., 2018; Theodor, Oldroyd, 1964]. The images taken with the digital microscope were edited using the free software program GNU Image Manipulation Program [GIMP team, 2019]. All Hippoboscidae examined have been maintained in the collection of the corresponding author. The nomenclature of louse flies follows the current world checklist [Dick, 2006], but in conformance with Doszhanov [2003], i.e. without taking into consideration the names of Ornithomya and Ornithoica subspecies.

The DNA barcoding was carried out in the Zoologische Staatssammlung (Bavarian State Collection of Zoology), Munich. We wanted to explore if we find evidence for cryptic species within our data. For this, we 
extracted the mitochondrial gene Cytochrome c oxidase subunit I (COI) of 32 individuals. A sample from the extraction, which was done using the Phenol-Chloroform extraction protocol [Sambrook et al., 1989]. The COI sequence was amplified using LepF1 and LepR1, purified with magnetic beads, and then sent them for Sanger Sequencing to the Sequencing Service at the Faculty of Biology, division of genetics, at the LudwigMaximillians-Universität München (LMU). After obtaining the sequences, we trimmed and made the consensus sequence using the program Geneious v5.5.9. After obtaining the consensus sequence for each sample, we downloaded sequences from Hippoboscidae of the same region of COI as ours from BOLD [Ratnasingham, Hebert, 2007] (Table 1). We aligned them using MAFFT [Katoh et al., 2002], and then uploaded the structing a phylogenetic tree using RAxML v.8.2.12 with 1,000 bootstrap replicates [Stamatakis, 2014].

To test if there are cryptic species within the data we applied a Generalized Mixed Yule Coalescent (GMYC) method, which is a likelihood method that combines the diversification between species with the genealogical branching within species for a single-locus, so that it can make a better reconstruction of species boundaries givthe analysis, we required an ultra-metric tree, which was estimated using the previously aligned sequences with BEAST v2 [Bouckaert et al., 2019]. We calculated the parameters using the associated application BEAUti. legs of these individuals was obtained for the DNA alignment to CIPRES [Miller et al., 2010] for reconen the data [Fujisawa, Barraclough, 2013]. For making

We used an GTR model, and we constrained the analysis to form two clades that represent the subfamilies Lipoteninae and Ornithomyinae. We uploaded the tree to the GMYC web server (Exelixis Lab, https://species.hits.org/gmyc/) and analysed the output for single and multiple thresholds.

To corroborate the results obtained from the GMYC, we uploaded the COI sequences to the BOLD database [Ratnasingham, Hebert, 2013], so that we could obtain the BIN (Barcode Index Number; which is equal for the individuals of the same species) for each sequenced individual of our sample. The BIN is a number that acts as an Operational Taxonomic Unit (OTU), in which any individual with the same BIN should have less than $2.2 \%$ of divergence with others with the same number. To obtain the BIN, the sequences that do not have the minimum quality are filtered (e.g. have less than $500 \mathrm{bp}$, have $1 \%$ approximately of ambiguous bases, have stop codons, or improbable COI peptides), then translated to amino acids, and aligned using a Hidden Markov Model to other sequences in the BOLD database [Ratnasingham, Hebert, 2013]. After the alignment took place, different methods were used for clustering: first a Single Linkage Clustering, in which sequences with less than $2.2 \%$ of divergence are clustered together, and then a Markov clustering that collapses to the same BIN those groups that show less than $4.4 \%$ divergence [Ratnasingham, Hebert, 2013]. The result is that each sequence becomes associated to a BIN number, either an already existing one or a newly established one, representing a new OTU.

Table 1. Reference samples for DNA-Barcoding. Таблица 1. Контрольные образцы для ДНК-штрих-кодирования.

\begin{tabular}{|l|l|l|l}
\hline & \multicolumn{1}{|c|}{ Species } & Country of origin & \multicolumn{1}{c}{ Collectors } \\
\hline H2 & Ornithomya avicularia & Germany & Doczkal, D. \& Voith, J. \\
\hline H3 & Ornithomya avicularia & Germany & Doczkal, D. \\
\hline GBDP292007 & Ornithomya chloropus & Germany & Michael Hupfer \\
\hline GBDP2839619 & Ornithomyia fringillina & Canada & $\begin{array}{l}\text { BOLD Systems, Mined from } \\
\text { GenBank, NCBI }\end{array}$ \\
\hline GBDP2839519 & Ornithomyia fringillina & Canada & $\begin{array}{l}\text { BOLD Systems, Mined from } \\
\text { GenBank, NCBI }\end{array}$ \\
\hline GBDP291707 & Ornithomyia fringillina & Germany & $\begin{array}{l}\text { BOLD Systems, Mined from } \\
\text { GenBank, NCBI }\end{array}$ \\
\hline GBDP1874615 & Ornithophila gestroi & ? & $\begin{array}{l}\text { BOLD Systems, Mined from } \\
\text { GenBank, NCBI }\end{array}$ \\
\hline GBDP2700619 & Lipoptena fortisetosa & Lithuania & $\begin{array}{l}\text { BOLD Systems, Mined from } \\
\text { GenBank, NCBI }\end{array}$ \\
\hline
\end{tabular}

Parentheses: subspecies concept of Maa, 1967; ? = data not given. Samples from Europe were incorporated into the analyses for taxonomic placement of the DNA barcodes. BOLD data was downloaded from the BOLD database, all other sequences were newly generated in this study.

В скобках: статус подвида принят по Маa, 1967;? = данные не указаны. Образцы из Европы были включены в анализ ДНК для сравнения. Данные BOLD были загружены из базы данных BOLD, все остальные последовательности были созданы заново в этом исследовании. 


\section{Results}

We collected a total of 100 louse flies of altogether seven species (Table 2) and recorded 91 breeding and migratory birds of 33 species being hosts. Furthermore,

Table 2. Species and abundance of louse flies from Muraviovka

Park.

Таблица 2. Виды и численность мух-кровососок в парке

Муравьевка.

\begin{tabular}{|l|c|c|}
\hline $\begin{array}{c}\text { Species and individuals with } \\
\text { unknown taxonomic status }\end{array}$ & $\mathrm{n}$ & $\%$ \\
\hline Icosta holoptera & 2 & 1,9 \\
\hline Ornithoica momiyamai & 5 & 2,8 \\
\hline Ornithoica unicolor & 1 & 0,9 \\
\hline Ornithomya aobatonis* & 81 & 75,7 \\
\hline "Ornithomya A"* & 1 & 0,9 \\
\hline Ornithomya chloropus & 7 & 6,5 \\
\hline Ornithomya fringillina & 7 & 6,5 \\
\hline "Ornithomya B"* & 1 & 0,9 \\
\hline Ornithophila metallica & 2 & 1,9 \\
\hline Total & 107 & 100 \\
\hline
\end{tabular}

$\mathrm{n}=$ number, $*$ result of DNA-barcoding

$\mathrm{n}=$ число экземпляров, * есть результат ДНК-штрихкодирования seven Hippoboscidae without assignment to a host were collected. In total, twelve times more females than males were caught.

Species identification by DNA Barcoding, faunistic results and hosts per species

The identification keys led us to eight different species and subspecies. Altogether 19 individuals were investigated by DNA barcoding. The samples of Icosta holoptera and Ornithoica unicolor did not produce any results in the context of the DNA barcoding, leaving 15 individuals with usable sequences. The results are shown in a maximum likelihood tree (Fig. 2). In this way, seven louse fly species and two different females of uncertain species level (cf. status) were identified. The taxonomic status of a further species was changed (stat.rev.) and three other species rsp. subspecies were recognized as synonyms of formerly described ones (see below). Flies of Ornithomya fringillina from Canada, Europe and the Russian Far East are located in the same barcoding cluster. In the case of Ornithomya fringillina and Ornithomya chloropus, records indicate a gap closure between the known eastern and western distribution areas of those species (see Doszhanov, 2003).

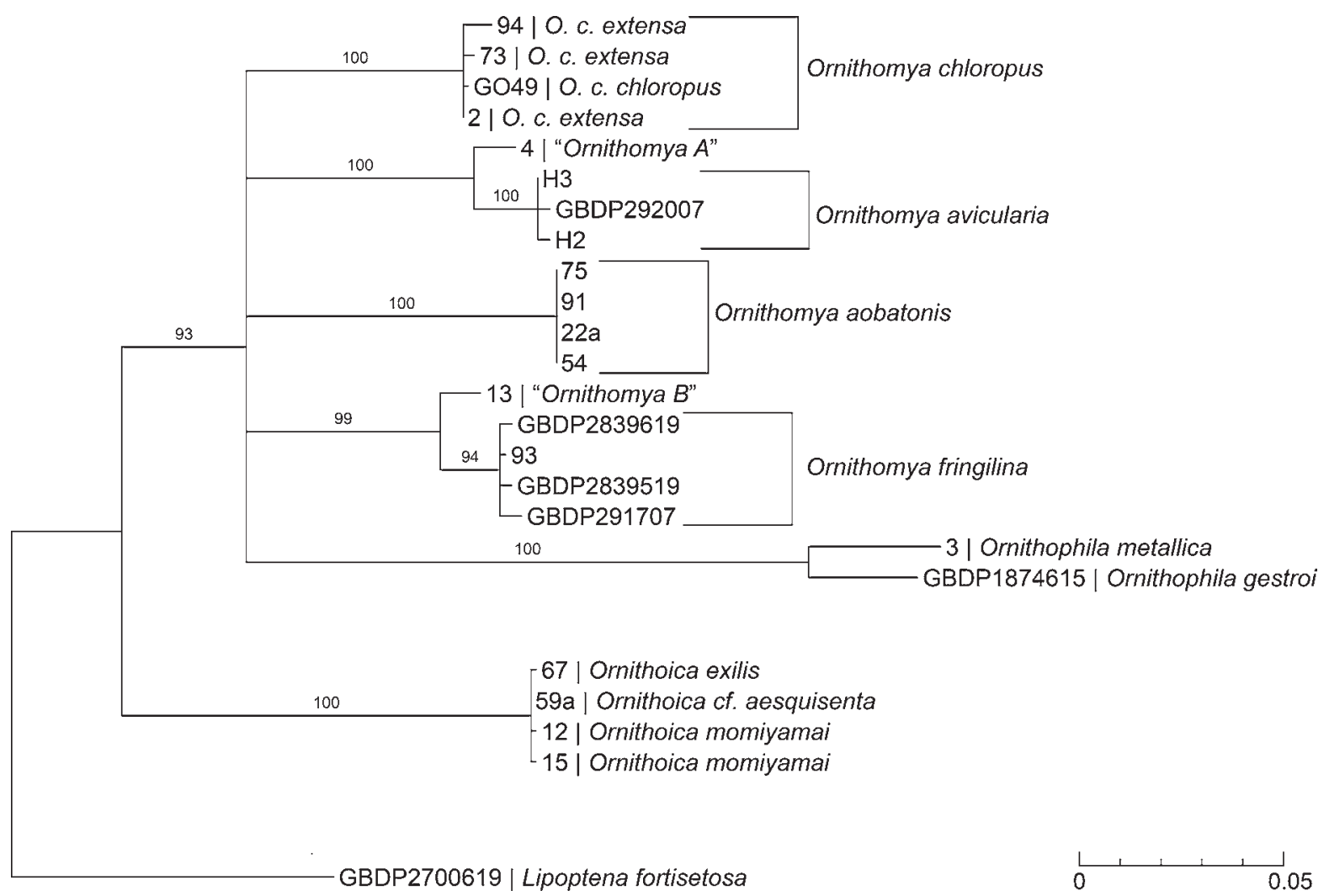

Fig. 2: Cytochrome c oxidase subunit I (COI) gene tree for Hippoboscidae. The tree was estimated using maximum likelihood (RAxML). COI sequences used to estimate the tree were obtained from some individuals from Muraviovka park, individuals recollected in Germany, and sequences downloaded from BOLD. Numbers above the branch are bootstrap values.

Рис. 2. Дерево субъединицы I цитохром с-оксидазы (COI) для Нippoboscidae. Сходство оценивалось с использованием метода максимального правдоподобия (RAxML). Последовательности COI, использованные для оценки дерева, были получены от образцов из парка Муравьёвка, а так же собранных в Германии, и последовательностей, загруженные из BOLD (Таблица 1). Цифры над узлами показывают бутстрап-значения. 


\section{Species account*}

Icosta holoptera (Lutz, 1915)

Fig. 3.

MATERIAL. 2 + 9 , 25.V.2017, host: both on one Gallinago stenura.

NOTE. New record for Russian Federation. Number of hosts: 1.

\section{Ornithoica momiyamai Kishida, 1932}

Fig. 4.

MATERIAL. + , 30.VIII.2017, host: Emberiza spodocephala; 1 o', 23.VIII.2017, host: Locustella certhiola; 1 q, 18.VIII.2017, host: Luscinia calliope; 1 q, 26.VII.2017, host: Parus major; 1 , 26.VII.2017, host: unknown.

NOTE. Number of hosts: 4.

Ornithoica unicolor Speiser, 1900

Fig. 5.

MATERIAL. + , 9. IX 2017, host: Asio otus.

NOTE. Number of hosts: 1.

Ornithomya aobatonis (Matsumura, 1905), stat.rev. Fig. 6

= Ornithomya avicularia aobatonis Matsumura, 1905

MATERIAL. $6 \sigma^{7} \sigma^{7}, 75$ 우, sex ratio: $1 \sigma^{7}: 13$ 우.

3 우, 19.VIII.2017, host: Accipiter gularis; 1 ㅇ, 12.VII.2017, leg. Koroschevsky, host: Acrocephalus aedon; 1 +, 29.VII.2017, host: Acrocephalus aedon; 1 + 29.VII.2017, host: Acrocephalus aedon; 1 + 21 .VIII.2017, host: Acrocephalus aedon; 1 + 17.VIII 2017, host: Acrocephalus bistrigiceps; 1 + , 31.VII.2017, host: Acrocephalus orientalis; 1 9, 17.VIII.2017, host: Anthus hodgsoni; 1 +, 10.IX.2017, host: Anthus hodgsoni; 1 + 16.IX.2017, host: Anthus hodgsoni; 1 O', 5.VIII.2017, host: Asio otus; 1 ○, 09.IX 2017, host: Asio otus; 1 ㅇ, 9.IX.2017, host: Asio otus; 1 ㅇ, 13.VIII 2017, host: Dendrocopos leucotos; 1 O', 2.VIII.2017, host: Dendrocopos major; 1 +, 2 .VIII.2017, host: Dendrocopos major; 1 , 13.VII.2017, leg. Korschefsky, host: Emberiza elegans; 1 9, 18.VIII. 2017, host: Emberiza rutila; 1 \%, 30.VI.2017, host: Emberiza spodocephala; 1 ㅇ, 26.VII.2017, host: Emberiza spodocephala; 1 +, 26.VII.2017, host: Emberiza spodocephala; 1 +, 28.VII.2017, host: Emberiza spodocephala; 1 9 , 29.VII.2017, host: Emberiza spodocephala; 1 + , 29.VII.2017, host: Emberiza spodocephala; 1 +, 30.VII.2017, host: Emberiza spodocephala; 1 + , 18.VIII.2017, host: Emberiza spodocephala; 1 ․ 19.VIII.2017, host: Emberiza spodocephala; 1 + , 19.VIII.2017, host: Emberiza spodocephala; 1 +, 20.VIII.2017, host: Emberiza spodocephala; 1 +, 24.VIII.2017, host: Emberiza spodocephala; 1 +, 28.VIII.2017, host: Emberiza spodocephala; 1 \% , 31.VIII.2017, host: Emberiza spodocephala; 1 +, 4.IX.2017, host: Emberiza spodocephala; 1 +, 6.IX.2017, host: Emberiza spodocephala; 1 9, 09.IX.2017, host: Emberiza spodocephala; 1 ㅇ, 27.VII.2017, host: Ficedula albicilla; 1 ㅇ 28.VII.2017, host: Ficedula albicilla; 1 +, 31.VII.2017, host: Ficedula albicilla; $1 \mathrm{O}^{7}$, 14.VIII.2017, host: Ficedula albicilla; 1 +, 15.VIII.2017, host: Ficedula albicilla; 1 +, 29.VII.2017, host: Ficedula zanthopygia; 1 + , 29.VII.2017, host: Ficedula zanthopygia; 1 + , 2.VIII.2017, host: Ficedula zanthopygia; 1 +, 12.VIII.2017, host: Ficedula zanthopygia; $1 \sigma^{2}, 14$. VIII.2017, host: Ficedula zanthopygia; 1 + , 16.VIII.2017, host: Ficedula zanthopygia $; 1$, 9.IX.2017, host: Gallinago gallinago; 1 + 19.VIII.2017, host: Gallinago stenura; 1 + , 23.VIII.2017, host: Locustella certhiola; 1 P, 23.VIII 2017, host: Locustella certhiola; 1 O 06.IX.2017, host: Locustella lanceolata; 1 + , 14.VIII.2017, host: Luscinia calliope; 1 + 1 17.VIII.2017, host: Luscinia calliope; 1 \% , 13.VIII. 2017, host: Muscicapa dauurica; 1 + , 25.VIII.2017, host: Muscicapa dauurica; 1 \% , 19.IX.2017, host: Ninox scutulata; 1 ㅇ, 22.VIII.2017, host: Otus sunia; 1 +, 22.VIII.2017, host: Otus

* unless stated otherwise noted, collectors of flies are Heim/ Meißner. sunia; 1 , 13.VII.2017, leg. Korschefsky, host: Parus major; 1 , 9.VIII.2017, host: Phylloscopus fuscatus; 1 , , 18.VIII.2017, host: Phylloscopus fuscatus; 1 \%, 28.VIII.2017, host: Phylloscopus fuscatus; 1 ㅇ, 31.VIII.2017, host: Phylloscopus fuscatus; 1 , 4.IX.2017, host: Phylloscopus fuscatus; 1 +, 1.IX.2017, host: Phylloscopus schwarzi; 1 +, 15.VIII.2017, host: Picus canus; 1 , 5.VII.2017, host: Saxicola maurus; 1 + , 10.IX.2017, host: Sitta europaea; 1 , , 16.IX.2017, host: Sitta europaea; $10^{7}, 20$. VIII.2017, host: Turdus hortulorum; 1 9, 9.IX.2017, host: Turdus hortulorum; 1 +, 10. IX.2017, host: Turdus hortulorum; 1 +, 4 .VIII.2017, host: Turdus pallidus; records with unknown hosts: 1 , 13 .VII. 2017, leg. Korschefsky; 1 ㅇ, 26.VII.2017; 1 ㅇ, 25.VIII.2017; 1 ㅇ, 29.VIII.2017; 1 ㅇ, 9.IX.2017; 1 ㅇ, 14.IX.2017.

NOTE. Number of hosts: 16.

\section{"Ornithomya A"}

MATERIAL. + , 24.VI.2017, host: Luscinia calliope. NOTE. Number of hosts: 1.

\section{Ornithomya chloropus Bergroth, 1901} Fig. 7.

MATERIAL. 1 , 10.IX.2017, host: Anthus hodgsoni; 1 , 18.IX.2017, host: Anthus hodgsoni; 1 + , 18.IX.2017, host: Anthus hodgsoni; 1 + , 6.IX.2017, host: Emberiza chrysophrys; 1 +, 21.VIII.2017, host: Emberiza spodocephala; 1 +, 12.IX.2017, host: Fringilla montifringilla; 1 +, 22.VI.2017, host: Passer montanus.

NOTE. Number of hosts: 5 .

Ornithomya fringillina Curtis, 1836

MATERIAL. + , 18.IX.2017, host: Anthus hodgsoni; 1 + 19.IX. 2017, host: Anthus hodgsoni; 1 + , 10.IX.2017, host: Emberiza pusilla; 1 + , 10.IX.2017, host: Emberiza pusilla; 1 + , 21.IX.2017, host: Emberiza pusilla; $1 \mathrm{O}^{7}$, 1.VIII.2017, host: Ficedula zanthopygia; 1 9, 8.VIII.2017, host: Ficedula zanthopygia.

NOTE. Number of hosts: 3 .

\section{"Ornithomya B"}

MATERIAL. + , 26.VII.2017, host: Ficedula zanthopygia. NOTE. Number of hosts: 1.

\section{Ornithophila metallica (Schiner, 1864)}

MATERIAL. OT, 21.VIII.2017, host: Acrocephalus aedon; 1 , 23.VI.2017, host: Luscinia calliope.

NOTE. Number of hosts: 2.

\section{Number of louse flies and louse fly species per} host

Usually, one louse fly was detected on each host. In four cases, two parasites of the same species were found on one bird (Icosta holoptera on Gallinago stenura, Ornithomya aobatonis each on two Acrocephalus aedon and one Otus sunia). Three specimens of Ornithomya aobatonis occurred on a single Accipiter gularis. In three cases, louse flies of different species were found each on a single host (Ornithomya aobatonis / Ornithoica momiyamai on Locustella certhiola, Ornithomya aobatonis/Ornithophila metallica on Acrocephalus aedon, Ornithomya aobatonis/Ornithoica unicolor on Asio otus).

\section{New infestation after recapture}

After the recapture of two hosts, their new infestation was detected in each case with the same louse fly species: Emberiza spodocephala XR17580, captured 
26.VII.17 (1 +, Ornithomya aobatonis), recaptured 19.VIII.17 (1 +, Ornithomya aobatonis); Luscinia calliope KA13207, captured 14.VIII.17 (1 +, Ornithomya aobatonis), recaptured 17.VIII.17 (1 +, Ornithomya aobatonis).
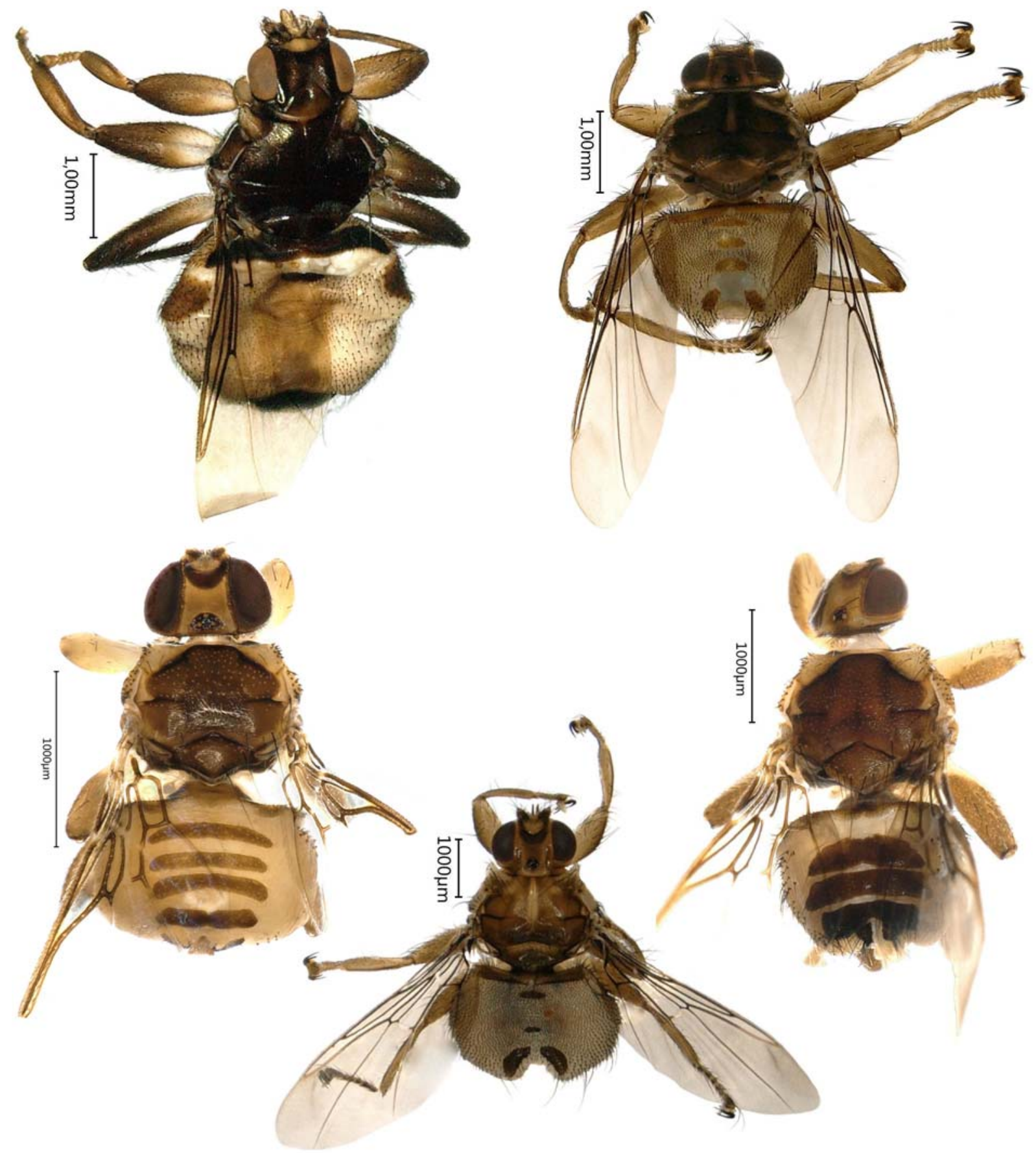

\section{Phoresy}

We observed phoretic mites (Acari) on five louse flies (5,6\% of all collected Hippoboscidae). These were three females of Ornithomya avicularia (phoresy ratio

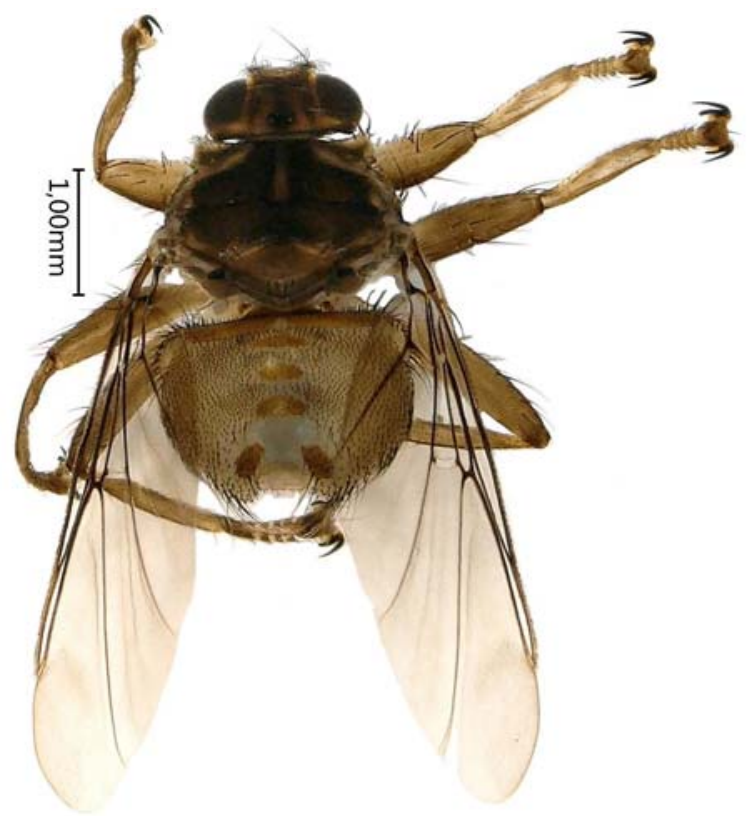

Figs 3-7. Hippoboscidae from Muraviovka Park, habitus, dorsal view: 3 - Icosta holoptera; 4 - Ornithoica momiyamai; 5 Ornithoica unicolor; 6 - Ornithomya aobatonis, stat.rev.; 7 - Ornithomya chloropus.

Рис. 3-7. Hippoboscidae парка Муравьёвка, внешний вид, сверху: 3 - Icosta holoptera; 4 - Ornithoica momiyamai; 5 Ornithoica unicolor; 6 - Ornithomya aobatonis, stat.rev.; 7 - Ornithomya chloropus. 
$3.7 \%$ ) and two females of Ornithomya chloropus (phoresy ratio $28.6, \%$ ). The birds acting as hosts were two Anthus hodgsoni, two Emberiza spodocephala and one
Ficedula albicilla, all of them juvenile birds. The mites (adults, eggs) were attached to the abdomen of the louse flies in all cases (Fig. 8).

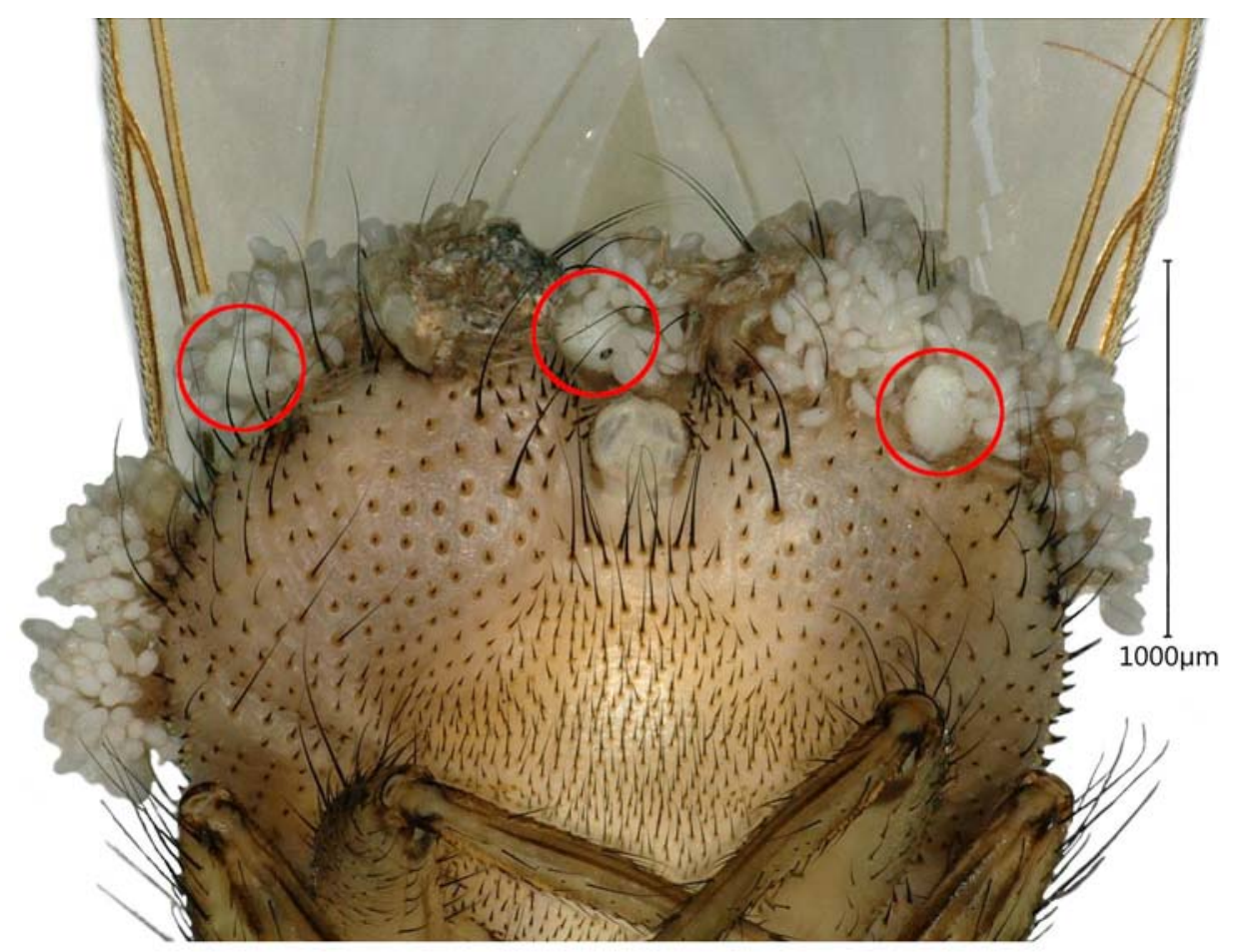

Fig. 8. Mites (circles) and mite eggs on abdomen of female Ornithomya avicularia, ventral view.

Рис. 8. Клещи (окружности) и их яйца на брюшке самки Ornithomya avicularia, снизу.

\section{Discussion}

With her extensive publications Maa [1962, 1963, $1966 \mathrm{a}-\mathrm{b}, 1969 \mathrm{a}-\mathrm{b}, 1967,1969 \mathrm{~b}-\mathrm{d}]$ created the basis for the faunistic research on louse flies of the whole world. She also described numerous subspecies, whose taxonomic differences, however, are hardly recognizable in many cases. In agreement with some relevant Russian authors (e.g. Farafonova, 2001; Doszhanov, 2003; Matyukhin, 2016), we therefore operate at the species level.

Sixteen louse fly species are known from the Russian Far East [Soós, Hùrka, 1986; Farafonova, 2001; Doszhanov, 2003; Nartshuk et al., 2018]. In our study we detected six of them, including one species with new taxonomic status, one species as a new record for the region, and two flies with divergent DNA barcodes that were marked as new OTUs ("Ornithomya A", Ornithomya B", Fig. 2). It should be noted, that the capture methodology did not cover the entire possible host range of the region. For this reason, and the fact that no louse flies from mammals were examined, the scope of the louse fly records is limited. In the sex ratio, a distinct majority of females was found, consistent with the observations of other authors (e. g. Theodor, Oldroyd, 1964; Soós, Hùrka 1986; Farafonova, 2001; Labitzke et al., 2018; Nartshuk et al., 2018; Knauthe, Jentzsch,
2019). The dominance of females might be explained by the earlier appearance of males in the season, which might cause them to die off sooner [Theodor, Oldroyd, 1964]. According to Büttiker [1994], males are also more mobile and can thus leave the host more quickly (e.g, already when taking the bird out of a net).

Doszhanov [2003] published distribution maps of the louse flies from the Russian Far East. For all species presented here with the exception of the new record Icosta holoptera and Ornithophila metallica (known from the region, see Nartshuk \& Matyukhin [2019]), these maps show a gap between the Eurasian area in the west, up to the Ob River and Novsibirsk, and the Sichote Alin Mountains, eastern Manchuria, Japan and Korea in the east. The present investigations extend the western boundary of this isolated area in the easternmost part, and in the case of Ornithomya chloropus our records suggest a gap closure between the eastern and the western distribution areas.

Icosta holoptera is one of the five species of the genus Icosta for Russia (see Doszhanov, 1977, 2003). So far, it has only been found in China (Zhejiang Province), the Malay Peninsula, the Philippines, New Guinea [Maa, 1969b] and Japan [Mogi et al., 2002]. Gruiformes and Charadriiformes are known as host birds, which is in concordance with our record on a Pintail Snipe (Charadriiformes) serving as host. 
Ornithomya avicularia aobatonis is used as a subspecies of $O$. avicularia in various recent publications [Dick, 2006; Sato, Mogi, 2008; Yamauchi, Kuroki, 2009; Suh et al., 2012], while in the annual checklist of the Catalogue of Life [2019] O. aobatonis (Matsamura, $1905)$ is listed as a valid species without reference. The current study provides two clearly separated COI barcodes, which supports the hypothesis of two distinct and valid species.

Discovery of cryptic species is one of the goals that can be achieved with DNA barcodes, although this method can only be a decision-making aid. In the case of Ornithomy a chloropus, there are discrepancies between different lines of evidence. The individuals of the numbers 2, 73 and 94 meet the characteristics of the subspecies Ornithomya chloropus extensa from Asia mentioned by Maa [1967: 738] and differ morphologically from Ornithomya chloropus chloropus from Europe, which suggests that both subspecies could be two different species. Based on the fact that the specimens of Ornithomya chloropus extensa from Muraviovka Park are retrieved as members of the same COI barcode cluster as Ornithomya chloropus chloropus GO49 from Europe (Fig. 2), there is no evidence for this hypothesis in the present case. Further investigations must clarify how morphological differences of Ornithomya chloropus from Europe and the Far East can be classified despite the common barcode cluster. Until further notice, the classification into two subspecies within the meaning of Maa [1967] continues.

The common barcoding results of Ornithomya fringillina from North America, Europe and Muraviovka Park leaves no doubt about the taxonomic classification of the species. But two further louse flies (named "Ornithomya A", "Ornithomya B") have unique COI sequences, each of which differs from the other clusters in the maximum likelihood tree. Morphological differences to the neighbouring species (Ornithomya avicularia and Ornithomya fringillina, respectively) could not be detected. Further research is necessary to clarify how this barcoding finding could be classified.

Winged louseflies reach their hosts by flying. In the case of louseflies that parasitize mammals, this can be observed regularly. In the case of louseflies parasitizing birds, however, this is difficult to prove. Breeding nests are usually mentioned as the point of contact between louse flies and birds [Büttiker 1994; Schöne, Schmäschke, 2015; own observations]. In the present case, two examples of louse flies are given, which had found birds outside of their breeding nests and in one case after a short time periode of maximum three days.

Five of the louse flies collected (5.6\%) served as phorents for mites and their egg deposits. The phoresy rate detected in this work is thus clearly above the value of $0.6 \%$ found by Matyukhin [2016] for the European part of Russia. Recent studies from Germany also show obvious differences in the proportion of louse flies used as a transport medium in Saxony, 1.0\% [Knauthe, Jentzsch, 2019] and Thuringia, 12.0\% [Labitzke et al., 2018]. The mites and mallophages are commonly found on the abdomen (Fig. 8) or wing base of the flies [Sellenschlo, 1984; Büttiker, 1994].

A total of 33 bird species were identified as hosts of louseflies and assigned to individual louse fly species (see results). We proved the occurrence of louse flies on rarely caught bird species such as Pintail Snipe, Brown Hawk Owl and Oriental Scops Owl for the very first time.

Acknowledgements. We are grateful to Sergei M. Smirenski and the staff of Muraviovka Park for enabling our work and to all volunteers who supported the bird ringing activities within in the Amur Bird Project, especially to Jonas Wobker, Hans-Jürgen Eilts and Vera Vladimirovna Volkova. We extend our heartfelt gratitude to Svetlana Pavlova (A.N. Severtsov Institute of Ecology and Evolution, Russian Academy of Sciences, Moscow) for the provision of scientific literature from Russia. Our thanks also go to Dieter Doczkal (Bavarian State Collection of Zoology, Munich, Germany) and Matthias Nuß (Senckenberg Natural History Collections Dresden, Germany) for taxonomic advice and further support of the project. Finally, it is fitting here that we also thank the German Academic Exchange Service and the International Office of the Dresden University of Applied Sciences, which supported the first author by means of a scholarship for a student internship in the Russian Far East. To the same extend, our thanks go to the Ludwig-Maximilians-Universität Munic and its Lehre@LMU funding programm, which enabled the sequencing work.

Competing interests. The authors declare no competing interests.

\section{References}

Bouckaert R., Vaughan T.G., Barido-Sottani J., Duchêne S., Fourment M., Gavryushkina A. et al. 2019. BEAST 2.5: An advanced software platform for Bayesian evolutionary analysis // PLOS Computational Biology. Vol.15. e1006650.

Büttiker W. 1994. Die Lausfliegen der Schweiz (Diptera, Hippoboscidae). Mit Bestimmungsschlüssel // Documenta Faunistica Helvetiae 15. Neuchâtel: CSCF. 117 S.

Catalogue of Life. 2019. http://www.catalogueoflife.org/annualchecklist/2019/details/database/id/101. Download 03.04.2020.

Dick C. W. 2006. Checklist of world Hippoboscidae (Diptera: Hippoboscoidea). Chicago: Field Museum of Natural History. 7 p.

Doszhanov T.N. 2003. [Louse-flies (Diptera, Hippoboscidae) of the Palaearctic] Mukhi-Krovososki (Diptera, Hippoboscidae) Palearktiki. Almaty: Institute of Zoology. 277 pp. [In Russian]

Eichler W. 1939. Deutsche Lausfliegen, ihre Lebensweise und ihre hygienische Bedeutung // Zeitschrift für hygienische Zoologie und Schädlingsbekämpfung Bd.31. S.210-226.

Farafonova G.V. 2011. [Hippoboscidae] // Lehr P.A. (ed.). Key to the insects of Russian Far East. Vol.VI. Diptera and Siphonaptera. Pt.2. Vladivostok: Dal'nauka. P.252-258 [in Russian].

Fujisawa T., Barraclough T. 2013. Delimiting Species Using SingleLocus Data and the Generalized Mixed Yule Coalescent Approach: A Revised Method and Evaluation on Simulated Data Sets // Systematic Biology. Vol.62. P.707-724.

Grebennikov V.V., Jendek E., Smirnov M.E. 2017. Diagnostic and phylogenetic utility of the first DNA barcode library for longhorn beetles (Coleoptera: Cerambycidae) from the Russian Far East // Zootaxa. Vol.4276. P.441-445.

Grunin K.J. 1989. 105. Family Hippoboscidae, 112. Family Oestridae, 113. Family Hypodermatidae // Bei-Bienko G.Ya. Key to the insects of the European part of the USSR. Vol.5. No.2. Leiden: Brill. P.979-986, 1104-1107, 1108-1110.

Heim W., Smirenski S.M. 2013. The Amur Bird Project at Muraviovka Park in Far-eastern Russia // BirdingASIA. Vol.19. P.31-33. 
Heim W. 2017. Population declines in eastern Palaearctic passerines // Vogelwelt. Vol.137. P.181-183.

Heim W., Eccard J.A., Bairlein F. 2018. Migration phenology determines niche use of East Asian buntings (Emberizidae) during stopover // Current Zoology. Vol.64. No.6. P.681-692.

Heim W., Smirenski S.M. 2017. The importance of Muraviovka Park/Far East Russia for endangered bird species on regional, national and international scale based on observations from 2011-2016 // Forktail. Vol.33. P.77-83.

Iwasa M., Choi C.-Y. 2013. Contribution to the Knowledge of the Hippoboscidae (Diptera) From the Republic of Korea // Journal of Medical Entomology. Vol.50. No.2. P.231-236.

Jentzsch M., Meissner B., Stubbe A., Stubbe M. Records of Hippoboscidae from Mongolian birds of prey with checklist-update // Exploration into the Biological Resources of Mongolia. [in prep.]

Katoh K., Misawa K., Kuma K., Miyata T. 2002. MAFFT: a novel method for rapid multiple sequence alignment based on fast Fourier transform. Oxford: University Press. No.30. P.30593066.

Kirichenko N., Triberti P., Akulov E., Ponomarenko M., Gorokhova S., Sheiko V., Ohshima I., Lopez-Vaamonde C. 2019. Exploring species diversity and host plant associations of leaf-mining micromoths (Lepidoptera: Gracillariidae) in the Russian Far East using DNA barcoding // Zootaxa. Vol.4652. P.1-55.

Knauthe C., Jentzsch M. 2019. Die Lausiegenfauna des Freistaats Sachsen (Diptera, Hippoboscidae) // Entomologische Nachrichten und Berichte. Bd.63. S.189-196.

Kristofik J., Kiefer M. 1983. Ectoparasitic flies (Diptera: Hippoboscidae, Nycteribiidae) from Mongolia // Biológia. Section B. Zoologia. Vol.38. No.2. P.199-203.

Labitzke V., Jentzsch M., Schönbrodt M. 2019. Lausfliegenerfassungen während der Vogelberingung am Helmestausee Berga-Kelbra (Diptera, Hippoboscidae) // Vogelwarte. Bd.57. S.73-81.

Lucius R., Loos-Frank B., Lane R.P. 2018. Biologie von Parasiten. Bd.3. Berlin, Heidelberg: Springer Spektrum. 268 S.

Maa T.C. 1962. Notes on the Hippoboscidae (Diptera), I // Pacific Insects. Vol.4. No.3. P.583-614

Maa T.C. 1963. Genera and species of Hippoboscidae (Diptera. types, synonymy, habitats and natural groupings // Pacific Insects Monograph. Vol.6. P.1-186.

Maa T.C. 1966a. Insects of Micronesia Diptera: Hippoboscidae; Streblidae // Insects of Micronesia. Vol.14. No.7. P.251-274.

Maa T.C. 1966b. The genus Ornithoica Rondani: Diptera: Hippoboscidae // Pacific Insects Monograph. Vol.10. P.10-124.

Maa T.C. 1967. A synopsis of diptera pupipara of Japan // Pacific Insects. Vol.9 No.2. P.4727-4760.

Maa T.C. 1969a. A revised checklist and concise host index of Hippoboscidae (Diptera) // Pacific Insects Monograph. Vol.20. P.261-299.

Maa T.C. 1969b. Revision of Icosta (= Lynchia auctt.) with erection of a related Genus Phthona (Diptera: Hippoboscidae) // Pacific Insects Monograph. Vol.20. P.25-203.

Maa T.C. 1969c. Notes on the Hippoboscidae II // Pacific Insects Monograph. Vol.2. No.20. P.237-260.

Maa T.C. 1969d. Synopses of the Genera Ornithophila and Ornithoctona with remarks on their Habitat Diversification (Diptera: Hippoboscidae) // Pacific Insects Monograph. Vol.20. P.1-23.

Maa T.C. 1977. Family Hippoboscidae // Delfinado, M.D., Hardy, D.E. A Catalog of the Diptera of the Oriental Region. Vol.3. Honolulu: The UniversityPress of Hawaii. P.407-418.

Makarchenko E.A., Makarchenko M.A., Semenchenko A.A. 2015. Morphological description and DNA barcoding of Hydrobae- nus majus sp. nov. (Diptera: Chironomidae: Orthocladiinae) from the Russian Far East // Zootaxa. Vol.4000. P.287-293.

Matyukhin A.V. 2016. The phoresy of the louse Mallophaga on the population of the louse-fly Hippoboscidae // Russian Journal of Parasitology. Vol.3. No.4. P.471-474.

Mehlhorn H., Piekarski G. 2002. Grundriss der Parasitenkunde. Parasiten des Menschen und der Nutztiere. Heidelberg: Springer Spektrum. $516 \mathrm{~S}$.

Meißner B. 2019. Erfassung von Vogel-Lausfliegen (Diptera, Hippoboscidae) im Rahmen des Amur Bird Project im Muraviovka Park für nachhaltige Landnutzung, Russland. Bachelor-Thesis. Dresden University of Applied Sciences. $47 \mathrm{~S}$.

Miller M.A., Pfeiffer W., Schwartz T. 2010. Creating the CIPRES Science Gateway for Inference of Large Phylogenetic Trees // Gateway Computing Environments Workshop (GCE). P.1-8.

Mogi M., Mano T., Sawada I. 2002. Records of Hippoboscidae, Nycteribiidae and Streblidae (Diptera) from Japan // Medical Entomology and Zoology. Vol.53. Suppl. 2. P.141-165.

Nartshuk E.P., Matyukhin A.V. 2019. The Louse Flies Ornithophila metallica (Schiner, 1864) and O. gestroi (Rondani, 1878) (Diptera, Hippoboscidae): Distribution and Association with Birds in the Palaearctic // Far Eastern Entomologist. Vol.355. P.23-28.

Nartshuk E.P., Matyukhin A.V., Red'kin Y.A. 2018. Association of the louse-flies of the genus Ornithoctona Speiser, 1902 (Diptera: Hippoboscidae) with birds and first record of $O$. australasiae (Fabricius, 1805) from the Russian Far East // Entomological Review. Vol.99. P.504-507.

Ratnasingham S., Hebert P.D.N. 2007. BOLD: The Barcode of Life Data System // Molecular Ecology Notes. Vol.7. P.355-364.

Sambrook J., Fritsch E.F., Maniatis T. 1989. Molecular cloning: a laboratory manual. New York: Cold Spring Harbor Laboratory Press. 1626 pp.

Sato M., Mogi M. 2008. Records of some blood-sucking flies from birds and bats of Japan (Diptera: Hippoboscidae, Nycteribiidae and Streblidae) // Rishiri Studies. Vol.27. P.41-48.

Schöne R., Schmäschke R. 2015. Lebensraum Federkleid. Bern: Haupt Verlag. $193 \mathrm{~S}$

Sellenschlo U. 1984. Hippoboscidae i. e. S. - Lausfliegen (Diptera, Brachycera, Pupipara) // Neue entomologische Nachrichten. Bd.9. S.1-16.

Soós A., Hurka K. 1986. Family Hippoboscidae // Soos A., Papp L. Catalogue of the palaearctic Diptera. Scatophagidae - Hypodermatidae. Vol.11. Amsterdam: Elsevier. P.215-226.

Stamatakis A. 2014. RAxML version 8: a tool for phylogenetic analysis and post-analysis of large phylogenies // Bioinformatics. Vol.30. P.1312-1313.

Sun X. 1999. Family Hippoboscidae // W. Xue, C. Chao (eds.). Flies of China. Vol.2. Shenyang: Liaoning Science and Technology Press. P.2256-2265.

Taberlet P., Coissac E., Pompanon F., Brochmann C., Willerslev E. 2012. Towards next-generation biodiversity assessment using DNA metabarcoding // Molecular ecology. Vol.21 P.20452050

Theodor D., Oldroyd H. 1964. Hippoboscidae // Lindner E. (Hrsg.) Die Fliegen der palaearktischen Region. Bd.12. Stuttgart: Schweizerbart. S.1-70.

Yamauchi T., Ozaki K. 2007. The louse fly Ornithoica exilis (Diptera: Hippoboscidae) collected from the Okinawa Rail Gallirallus okinawae (Gruiformes: Rallidae) // Journal of the Yamashina Institute for Ornithology. Vol.38. No.2. P.97-99. 